\title{
Organ Formation from Calli and Protoplast Isolation, Culture, and Fusion in Apple, Malus pumila Mill.
}

\author{
Akira SAIto ${ }^{1}$, Minoru Nilzeki ${ }^{2}$ and Ken-ichi SAIto ${ }^{2}$ \\ ${ }^{1}$ Division of Disease and Insect Pest, Aomori Apple Experiment Station, \\ Kuroishi, Aomori 036-03 \\ ${ }^{2}$ Faculty of Agriculture, Hirosaki University, Hirosaki, Aomori 036
}

\begin{abstract}
Summary
Regeneration from nucellus calli was investigated to obtain basic data for somatic cell hybridization in apple Malus pumila Mill. In addition, isolation, culture and fusion of protoplasts derived from nucellus calli and leaves of the cultured shoots in vitro were investigated. The results are summarized as follows: 1 . Calli derived from nucellus 50 days after anthesis of a cultivar 'Fuji' and a rootstock 'CG 80' produced adventitious embryos. Some of the embryos germinated and formed shoots after they were placed at $0^{\circ} \mathrm{C}$ in the dark for 6 months and then transferred to $25^{\circ} \mathrm{C}$ in the light. 2. The enzyme solutions containing $2 \%$ Cellulase Onozuka R-10 and $0.1 \%$ Pectolyase Y-23 or $2 \%$ Cellulase Onozuka RS and $0.1 \%$ Pectolyase Y-23 were the most effective for protoplast isolation from the nucellus calli and the leaves of shoots. The yield of protoplasts was the highest from the calli and the leaves of shoots cultured for 16 20 days after transfer onto the new medium, except for a rootstock ' $\mathrm{M}$. 26' where the highest yield was with $21 \sim 30$ days of culture. The effective period of enzyme treatment on protoplast yield was $3.0 \sim 4.0 \mathrm{~h}$. Colony formation from protoplasts derived from nucellus calli was observed in all media used, except for the medium without growth regulators. 3. Somatic hybrid cells were produced by fusion of protoplasts isolated from the nucellus calli and the leaves of cultured shoots. Most of the hybrid protoplasts were identified by larger green protoplasts than the single green leaf protoplasts. The hybrid protoplasts and transparent nucellus callus protoplasts divided within $7 \sim 10$ days of culture, while the single leaf protoplasts and the fused homokaryotic leaf protoplasts could not divide. The hybrid cells divided several times, and still had green chloroplasts. Successive cell division gave rise to cell colonies, and the green chloroplasts disappeared gradually. The colonies grew into calli which are, however, not identified as to whether they are hybrids.
\end{abstract}

\section{Introduction}

Most improvements in apple, Malus pumila Mill., have been achieved by cross breeding. In this method, the genotypes of trees in $F_{1}$ generation may segregate because of the high heterozygosity of their parents. Therefore, combinations of agriculturally useful traits of both parents are very rare in the $F_{1}$ trees. Thus, the selection of the $F_{1}$ having the useful traits of both parents is very difficult and requires a large population. In addition, a long time is needed for selection of favourable $F_{1}$ trees because of their long juvenile period.

Received for publication June 15, 1988.
Somatic cell hybridization in apple may overcome the above problems because in this procedure no genotypic segregation of both parents occurs. Furthermore, there is the possibility for introduction of agriculturally useful genes from wild species or rootstocks. In order to make a success of somatic cell hybridization, isolation of protoplasts from appropriate organs or cultured tissues, fusion of genetically different protoplasts and regeneration from the hybrid protoplasts are required. In fruit trees, however, research on regeneration from cultured tissues and cells is very rare. Only in pear (24), peach(3) and Citrus (9), has the regeneration from calli derived from the immature 
embryo and nucellus been reported. In apple, there is a considerable number of reports of adventitious embryo or shoot regeneration directly from cultured organs such as leaf(4, $22)$, nucellus $(2,5)$, immature embryo $(10,12$, 13,21), seedling(14) and root(15), while there are very few reports of regeneration from calli or cultured cells $(11,17)$. In addition, there is a considerable number of reports concerning the isolation and culture of protoplasts derived from cultured tissues and cells $(1,7,11,20)$ or leaf $(6,16,23)$. However, in somatic cell hybridization in apple, not only the methods of protoplast isolation and culture but also of the regeneration from the cultured tissues or cells have not been completely established. We report here the experimental results concerning organ formation from nucellus calli, and protoplast isolation, culture and fusion, by using nucellus calli and leaves of cultured shoots in vitro of several cultivars and rootstocks. This may be the first report of somatic cell fusion between cultivars, or cultivars and rootstocks of Malus pumila.

\section{Materials and Methods}

\section{Regeneration from nucellus calli}

In a preliminary examination, organ regeneration from nucellus calli was attempted by using a cultivar 'Fuji' and a rootstock 'CG 80'. Immature seeds 50 and 100 days after anthesis were sterilized by $70 \%$ ethanol for 5 min and then sodium hypochlorite $(\mathrm{Cl}$ concentration; $0.5 \%)$ for $5 \mathrm{~min}$. Both sterilizing

Table 1. Medium compositions used for callus formation from nucellus.

\begin{tabular}{ll}
\hline \hline Medium type & \multicolumn{1}{c}{ Medium composition ${ }^{z}$} \\
\hline $\mathrm{Na}$ & $\mathrm{MS}$ \\
$\mathrm{Nb}$ & $\mathrm{MS}+0.5 \mathrm{mg} / l 2,4-\mathrm{D}$ \\
$\mathrm{Nc}$ & $\mathrm{MS}+1.0 \mathrm{mg} / l \mathrm{NAA}$ \\
$\mathrm{Nd}$ & $\mathrm{MS}+2.0 \mathrm{mg} / l 2,4-\mathrm{D}+0.5 \mathrm{mg} / l \mathrm{BAP}$ \\
$\mathrm{Ne}$ & $\mathrm{MS}+2.0 \mathrm{mg} / l \mathrm{NAA}+0.5 \mathrm{mg} / l \mathrm{BAP}$ \\
$\mathrm{Nf}$ & $\mathrm{MS}+2.0 \mathrm{mg} / l \mathrm{IBP}+0.5 \mathrm{mg} / l \mathrm{BAP}$ \\
$\mathrm{Ng}$ & $\mathrm{MS}+3.0 \mathrm{mg} / l \mathrm{NAA}+10 \mathrm{mg} / l \mathrm{BAP}$ \\
\hline mS: Basic medium of Murashige and Skog (1962). \\
2, 4-D : 2, 4-dichlorophenoxyacetic acid. \\
$\mathrm{NAA}:$ 1-naphthaleneacetic acid. \\
IBA : Indole-3-butyric acid. \\
BAP: 6-benzylaminopurine. \\
All media contained $30 \mathrm{~g} / l$ sucrose and were adjusted \\
to pH 5. 8.
\end{tabular}

solutions contained $0.1 \%$ Tween 20 . The seeds were then washed 5 times with sterilized distilled water. Nucelli were taken out from the seeds and then cultured on the media indicated in Table 1. All cultures were kept at $25^{\circ} \mathrm{C}$ under dark conditions. After 60 days of culture, frequencies of the formed calli were examined. For the induction of adventitious embryos, the calli were then transferred onto the MS basic medium(19) supplemented with $0.1 \mathrm{mg} / \mathrm{l}$ indole-3-acetic acid (IAA) and $0.1 \mathrm{mg} / \mathrm{l}$ kinetin.

Isolation and culture of protoplasts derived from nucellus calli and leaves of cultured shoots in vitro

The effect of enzyme composition and concentration on protoplast isolation was investigated. The enzyme solutions used are indicated in Table 2. All solutions contained $0.7 \mathrm{M}$ mannitol and were adjusted to $\mathrm{pH}$ 5.8. The calli used for protoplast isolation were nucellus calli of a rootstock ' $\mathrm{CG} \mathrm{80'} \mathrm{cultured} \mathrm{on} \mathrm{MS}$ basic medium containing $4 \mathrm{mg} / \mathrm{l}$ 2, 4dichlorophenoxyacetic acid $(2,4-\mathrm{D})$ and leaves of cultured shoots of a cultivar 'Oorin' on the MS basic medium containing $3 \mathrm{mg} / \mathrm{l} 6-$ benzyl aminopurine (BAP). Both materials 20 days after culture on the new media were used for protoplast isolation and $0.2 \sim 0.3 \mathrm{~g}$ of nucellus calli and $0.5 \mathrm{~g}$ of leaves of the cultured shoots cut into small pieces were treated with $18 \mathrm{ml}$ of enzyme solution at $28^{\circ} \mathrm{C}, 60$ shakes per min for $3.5 \mathrm{~h}$. Then, the obtained protoplasts were isolated by 8 sheets of gauze, and washed 4 times with $0.7 \mathrm{M}$ mannitol solution adjusted to $\mathrm{pH} 5.8$ under centrifugation at $80 \times \mathrm{g}$. The yield of protoplasts was determined by protoplasts resuspended in $0.5 \mathrm{ml}$ of the culture medium.

The effect of culture period of calli and shoots on protoplast isolation was also investigated. Nucellus calli of the cultivar 'Fuji' and the rootstock ' $\mathrm{CG} 80$ ' and cultured shoots

Table 2. Enzyme compositions and concentrations for protoplast isolation.

\begin{tabular}{|c|c|c|c|c|}
\hline \multirow[b]{2}{*}{ Enzyme } & \multicolumn{4}{|c|}{ Enzyme concentration $(\%)$} \\
\hline & $\mathrm{E}-1$ & $\mathrm{E}-2$ & $\mathrm{E}-3$ & $\mathrm{E}-4$ \\
\hline Cellulase Onozuka RS & - & - & 2.0 & - \\
\hline Cellulase Onozuka R-10 & 2.0 & 2.0 & - & 4.0 \\
\hline Pectolyase Y-23 & 0.1 & 0.4 & 0.1 & 0.1 \\
\hline
\end{tabular}


Table 3. Compositions and concentrations of growth regulators for protoplast culture.

\begin{tabular}{c|ccc}
\hline \multicolumn{1}{|c|}{$\begin{array}{c}\text { Concentrations of IBA } \\
(\mathrm{mg} / l)\end{array}$} & 0.0 & 1.0 & 2.0 \\
$\begin{array}{c}\text { Concentration } \\
\text { of BAP (mg/l) }\end{array}$ & & & \\
\hline 0.0 & $\mathrm{~A}^{\mathrm{z}}$ & $\mathrm{D}$ & $\mathrm{G}$ \\
0.5 & $\mathrm{~B}$ & $\mathrm{E}$ & $\mathrm{H}$ \\
1.0 & $\mathrm{C}$ & $\mathrm{F}$ & $\mathrm{I}$ \\
\hline
\end{tabular}

z A I : Type of medium.

of cultivars 'Oorin', 'Hokuto' and 'Starking', and rootstock 'M. 26' were used. Culture period was 10 15, 16 20 and 21 30 days after transferring the calli and shoots onto the new media. In addition, period of enzyme treatment was examined by using the same materials. The enzyme solution used in these examinations was E-1 (Table 2) which contains $2 \%$ Cellulase Onozuka R-10 and $0.1 \%$ Pectolyase Y-23. Procedures of protoplast isolation and yield determination were the same as described above.

The effect of medium composition on colony formation from protoplasts was also investigated. In this experiment, protoplasts isolated from nucellus calli of the cultivar 'Fuji' were used. The basic medium was $8 \mathrm{p}(8)$ and growth regulators were combined as shown in Table 3. Falcon plastic dishes $(35 \times 10 \mathrm{~mm})$ were used for all protoplast cultures. The dishes were sealed with parafilm and placed in a plastic moisture box at $25^{\circ} \mathrm{C}$ in the dark. After one week of culture, fresh medium was added to the dishes which were then moved into the light. After 60 days, colony formation was examined by the naked eye.

\section{Protoplast fusion}

Protoplasts isolated from nucellus calli of the cultivar 'Fuji' and from the leaves of cultured shoots of cultivars 'Oorin', 'Senshu' and 'Starking' were fused by the method of PEG-DMSO (PEG; polyethylene glycol, DMSO ; dimethylsulfoxide)(18). Concentrations of PEG 1540 were $25 \%$ or $50 \%$ and 10 $\%$ DMSO was added to the PEG solution. After $10 \mathrm{~min}$ of fusion treatment, PEG was washed 3 times by $0.7 \mathrm{M}$ mannitol with 0.05 $\mathrm{M} \mathrm{CaCl} 2 \cdot 2 \mathrm{H}_{2} \mathrm{O}$, then washed 4 times by cultured medium. Culture conditions were the same as those of protoplasts derived from nucellus calli, but the medium used was $8 \mathrm{p}$ basal con-

Table 4. Callus formation from nucelli of an apple cultivar and a rootstock, and adventitious embryo regeneration from the calli.

\begin{tabular}{|c|c|c|c|c|c|c|}
\hline \multirow{2}{*}{$\begin{array}{l}\text { Cultivar } \\
\text { or } \\
\text { rootstock }\end{array}$} & \multirow{2}{*}{$\begin{array}{l}\text { Stage } \\
\text { of } \\
\text { fruits }\end{array}$} & \multicolumn{3}{|c|}{$\begin{array}{l}\text { Callus formation from } \\
\text { nucelli }\end{array}$} & \multicolumn{2}{|c|}{$\begin{array}{l}\text { Adventitious embryo formation } \\
\text { from the calliw }\end{array}$} \\
\hline & & $\begin{array}{l}\text { medium } \\
\text { type }\end{array}$ & $\begin{array}{l}\text { No. of nucelli } \\
\text { used }\end{array}$ & $\begin{array}{l}\text { No. of nucelli } \\
\text { formed callus }\end{array}$ & $\begin{array}{l}\text { No. of calli } \\
\text { used }\end{array}$ & $\begin{array}{l}\text { No. of calli } \\
\text { formed embryo }\end{array}$ \\
\hline \multirow[t]{12}{*}{ Fuji } & 50 & $\mathrm{Na}$ & 30 & $0(0)^{x}$ & - & - \\
\hline & & $\mathrm{Nb}$ & 30 & $12(40)$ & 10 & $0(0)^{x}$ \\
\hline & & $\mathrm{Nc}$ & 30 & $12(40)$ & 10 & $0(0)$ \\
\hline & & $\mathrm{Nd}$ & 30 & $16(53)$ & 10 & $1(10)$ \\
\hline & & $\mathrm{Ne}$ & 30 & $14(47)$ & 10 & $0(0)$ \\
\hline & & $\mathrm{Nf}$ & 30 & $18(60)$ & 10 & $0(0)$ \\
\hline & & $\mathrm{Ng}$ & 30 & $12(40)$ & 10 & $1(10)$ \\
\hline & 100 & $\mathrm{Na}$ & 20 & $6(30)$ & 6 & $0(0)$ \\
\hline & & $\mathrm{Nd}$ & 30 & $24(80)$ & 10 & $0(0)$ \\
\hline & & $\mathrm{Ne}$ & 30 & $20(67)$ & 10 & $0(0)$ \\
\hline & & $\mathrm{Nf}$ & 18 & $16(89)$ & 10 & $0(0)$ \\
\hline & & $\mathrm{Ng}$ & 30 & $18(60)$ & 10 & $0(0)$ \\
\hline \multirow[t]{3}{*}{ CG 80} & 50 & $\mathrm{Na}$ & 30 & $0(0)$ & - & - \\
\hline & & $\mathrm{Nb}$ & 30 & $12(40)$ & 10 & $0(0)$ \\
\hline & & $\mathrm{Ng}$ & 30 & 14 (47) & 10 & $1(10)$ \\
\hline
\end{tabular}

z Stage of fruits: No. of days after anthesis.

y Medium type corresponds to Table 1 .

$x()$ : Percentage.

w For adventitious embryo formation, the calli were cultured on MS basic medium supplemented with $0.1 \mathrm{mg} / \mathrm{l}$ IAA and $0.1 \mathrm{mg} / l$ kinetin. 


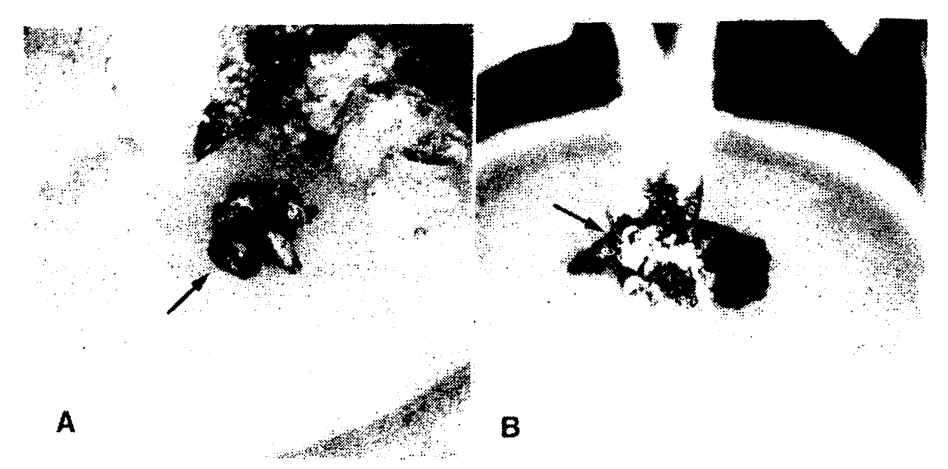

Fig. 1. Adventitious embrio formation from the nucellus-derived callus and germination of the embryo in a cultivar ' $F$ uji'.

A : A formed adventitious embryo indicated by an arrow.

B: A germinated embryo indicated by an arrow.

taining $0.2 \mathrm{mg} / \mathrm{l} 2,4-\mathrm{D}, 1.0 \mathrm{mg} / \mathrm{l} 1$-naphthalenacetic acid (NAA) and $0.5 \mathrm{mg} / l \mathrm{BAP}$. Formed colonies were transplanted onto the MS basic medium containing $0.1 \mathrm{mg} / l$ IAA and $0.1 \mathrm{mg} / \mathrm{l}$ kinetin and solidified by $0.8 \%$ agar.

\section{Results and Discussion}

\section{Regeneration from nucellus calli}

Callus formation from the nucelli 50 and 100 days after anthesis of the cultivar ' $\mathrm{Fuji}$ ' and 50 days after anthesis of the rootstock 'CG 80', and the regeneration of adventitious embryos from the calli are indicated in Table 4. Na medium with no growth regulator did not form any callus derived from the nucellus on 50 days after anthesis, in both 'Fuji' and 'CG 80'. On the other media with growth regulators shown in Table 1, 40 60\% of nucelli formed calli. With 'Fuji', nuceli 100 days after anthesis showed considerably higher callus formation than the 50-day nucelli. Indeed, the frequencies of callus formation were about $60 \sim 90 \%$, and even on the medium without growth regulator $30 \%$ of nucelli formed calli. Adventitious embryo formation was, however, observed only on the calli derived from nucelli 50 days after anthesis, although the frequencies of adventitious embryos were not so high (Fig. 1-A). This may support the results of Hammerschlag et al. (3) in which regeneration required callus induced from juvenile tissues or organs.

The adventitious embryos formed were morphologically similar to those indicated by
Table 5. Effect of enzyme compositions and concentrations on the yield of protoplasts.

\begin{tabular}{lccc}
\hline $\begin{array}{l}\text { Source } \\
\text { materials }\end{array}$ & $\begin{array}{l}\text { Enzyme } \\
\text { composition }^{z}\end{array}$ & $\begin{array}{l}\text { Yield of } \\
\text { protoplasts }^{y}\end{array}$ & $\begin{array}{l}\text { Test } \\
\text { frequency }^{2}\end{array}$ \\
\hline Nucellus calli & E-1 & + & 3 \\
(CG 80) & E-2 & \pm & 3 \\
& E-3 & + & 3 \\
& E-4 & + & 3 \\
Leaves of & E-1 & + & 3 \\
cultured shootsE & -2 & \pm & 3 \\
(Oorin) & E-3 & + & 3 \\
& E-4 & + & 4 \\
\hline
\end{tabular}

2 $\mathrm{E}-1 \sim \mathrm{E}-4$ correspond to Table 2.

y + : More than $10^{6} / \mathrm{ml}$.

$+: 10^{6} \sim 10^{5} / \mathrm{ml}$.

\pm : Less than $10^{5} / \mathrm{ml}$.

- : Not isolated protoplast.

The yield of protoplasts was determined by protoplasts resuspended in $0.5 \mathrm{ml}$ of the cultured medium.

Ishihara and Ooya(5) and Eichholtz et al.(2). Some of the embryos germinated and formed shoots when they were placed at $0^{\circ} \mathrm{C}$ in the dark for 6 months and then transferred to $25^{\circ} \mathrm{C}$ in the light (Fig. 1-B).

\section{Protoplast isolation and culture}

Table 5 shows the effect of enzyme composition on protoplast isolation. From about $0.2 \sim 0.3 \mathrm{~g}$ of nucellus calli, a high yield of intact protoplasts, more than $10^{6} / \mathrm{ml}$, was obtained by enzyme solution E- 1 and E-3, which contain $2 \%$ Cellulase Onozuka R-10 and $0.1 \%$ Pectolyase Y-23, and $2 \%$ Cellulase Onozuka RS and $0.1 \%$ Pectolyase Y-23. The use of E-2 and E-4 enzyme solutions decreased 
intact protoplasts. These results seem to be due to high concentrations of enzymes such as $0.4 \%$ Pectolyase $\mathrm{Y}-23$ in the E-2 and $4.0 \%$ Cellulase Onozuka R-10 in the E-4, which might injure the protoplasts in the process of protoplast isolation. From leaves of cultured shoots, the yield of intact protoplasts was fairly low such as $10^{5} \sim 10^{6} / \mathrm{ml}$ by the E-1, E-3 and $\mathrm{E}-4$, and less than $10^{5} / \mathrm{ml}$ by the E-2. From the results mentioned above, the E-1 and E-3 enzyme solutions were comparably better among 4 enzyme solutions for protoplast isolation from both nucellus calli and leaves of cultured shoots, while they were not completely satisfactory in the case of the cultured shoots, because a considerable number of nonintact protoplasts occurred. The relation between yield of protoplasts and culture period of source materials for protoplasts after transferring to the new medium is indicated in Table 6. A high yield of protoplasts was obtained from the nucellus calli cultured for 16 $\sim 20$ days. The yield of protoplasts was also higher in the case of the leaves of shoots in the cultivars 'Oorin', 'Hokuto', 'Senshu' and 'Starking' cultured for $16 \sim 20$ days than for other shorter or longer periods, while the highest yield of protoplasts was produced in shoots of the rootstock 'M. 26' cultured for 21 $\sim 30$ days. This is likely to be the result of very slow shoot growth in rootstock 'M. 26' compared with the other cultivars.

Effect of period of E-1 enzyme treatment on the yield of protoplasts is shown in Table 7 . The highest protoplast isolation, $10^{6} / \mathrm{ml}$, from nucellus calli was obtained by $3.5 \mathrm{~h}$ treatment. Protoplast isolation from the leaves of cultured shoots was also the highest under treatment of $3.0 \sim 4.0 \mathrm{~h}$.

Colony formation from nucellus protoplasts in various media used is shown in Table 8. There was no conspicuous difference among media except for the medium without growth regulator which did not form a colony. On the other hand, cell division and colony formation from the leaf protoplasts could not be observed in any media used.

Fusion of protoplasts and culture

Fused protoplasts were obtained between the protoplasts from nucellus calli of the cultivar 'Fuji' and those from the leaves of cultured
Table 6. Effect of culture period on protoplast yield.

\begin{tabular}{|c|c|c|c|c|}
\hline \multirow{3}{*}{$\begin{array}{l}\text { Source of } \\
\text { protoplasts }\end{array}$} & \multirow{3}{*}{$\begin{array}{l}\text { Cultivars and } \\
\text { rootstocks }\end{array}$} & \multicolumn{3}{|c|}{ Yield of protoplasts ${ }^{z}$} \\
\hline & & \multirow{2}{*}{\multicolumn{3}{|c|}{$\begin{array}{ccc}\text { Culture duration (days) } & \text { dura } \\
10 \sim 15 & 16 \sim 20 & 21 \sim 30\end{array}$}} \\
\hline & & & & \\
\hline \multirow{2}{*}{$\begin{array}{l}\text { Nucellus } \\
\text { calli }\end{array}$} & 'Fuji' & \pm & H & + \\
\hline & ‘CG 80’ & \pm & H & + \\
\hline \multirow{5}{*}{$\begin{array}{l}\text { Leaves of } \\
\text { cultured } \\
\text { shoots }\end{array}$} & 'Oorin’ & + & H & + \\
\hline & 'Hokuto' & + & H & + \\
\hline & 'Senshu' & + & H & + \\
\hline & 'Starking' & + & $H$ & + \\
\hline & 'M. 26' & \pm & + & H \\
\hline
\end{tabular}

$\mathrm{z}+,+, \pm:$ The same as Table 5 .

Table 7. Effect of period of enzyme treatment on protoplast yield.

\begin{tabular}{lccc}
\hline $\begin{array}{l}\text { Source of } \\
\text { protoplasts }\end{array}$ & $\begin{array}{l}\text { Period of } \\
\text { enzyme } \\
\text { treatment }(\mathrm{h})\end{array}$ & $\begin{array}{l}\text { Protoplast } \\
\text { yield }^{\mathrm{z}}\end{array}$ & $\begin{array}{l}\text { Test } \\
\text { frequency }\end{array}$ \\
\hline Nucellus calli & 1.0 & - & 2 \\
(CG 80) & 2.5 & + & 2 \\
& 3.5 & + & 3 \\
& 4.5 & + & 3 \\
Leaves of & 1.0 & - & 3 \\
cultured shoots & 2.5 & \pm & 3 \\
(Oorin) & $3.0-4.0$ & + & 3 \\
& $5.0-6.0$ & + & 2 \\
\hline
\end{tabular}

z,,,,++ \pm- : The same as Table 5 .

Table 8. Effect of medium compositions on colony formation from nucellus callus protoplasts.

\begin{tabular}{ccc}
\hline $\begin{array}{l}\text { Medium } \\
\text { ty pe }^{z}\end{array}$ & $\begin{array}{c}\text { No. of } \\
\text { culture dishes }\end{array}$ & $\begin{array}{c}\text { No. of culture } \\
\text { dishes formed colony }\end{array}$ \\
\hline A & 5 & 0 \\
B & 5 & 2 \\
C & 5 & 3 \\
D & 5 & 3 \\
E & 5 & 3 \\
F & 5 & 3 \\
G & 5 & 3 \\
H & 5 & 2 \\
I & 5 & 2 \\
\hline
\end{tabular}

z A I correspond to Table 3 .

shoots of cultivars 'Oorin', 'Senshu' and 'Starking'. The protoplasts derived from nucellus calli were transparent with large. vacuoles and had no green chloroplasts (Fig. 2-A). Sizes of the protoplasts were $12 \sim 65 \mu \mathrm{m}$ with a mean size of $32 \mu \mathrm{m}$. On the other hand, the protoplasts derived from the leaves of cultured 


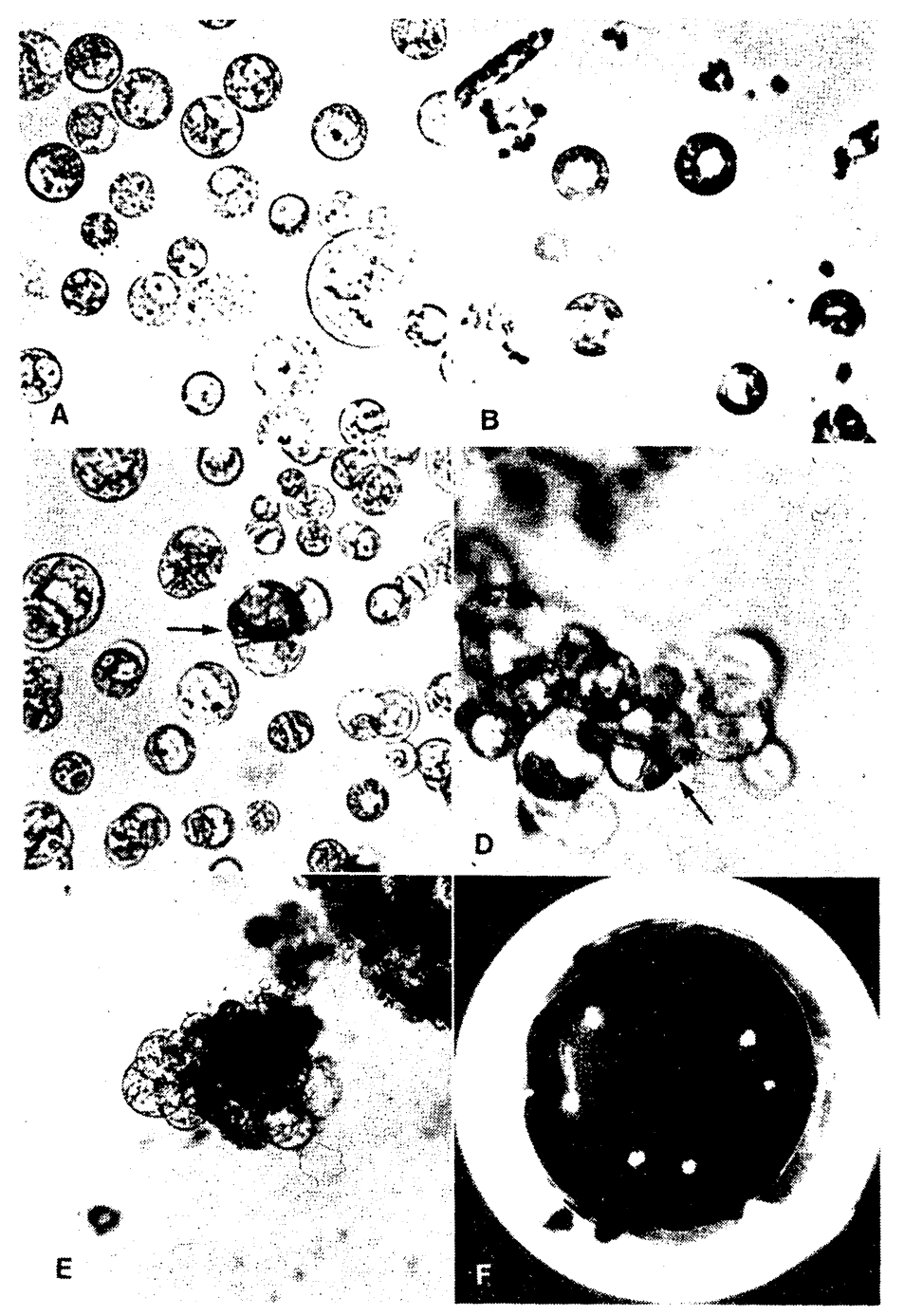

Fig. 2. Protoplast isolation, fusion and culture.

A: Protoplasts isolated from the nucellus calli of a cultivar 'Fuji'. B: Mesophyll protoplasts isolated from the leaves of cultured shoots of a cultivar 'Oorin'. C: A fused heterokaryotic protoplast indicated by an arrow. D: A divided hybrid cell (indicated by an arrow) which maintained green chloroplasts. E: A formed cell cluster in which the green chloroplasts disappeared after 30 days. F: Formed colonies in which the hybrids were not identified.

shoots had green chloroplasts (Fig. 2-B). Sizes of the protoplasts were $9 \sim 26 \mu \mathrm{m}$, with a mean size of $14 \mu \mathrm{m}$. Therefore, after fusion treatment, most of the hybrid protoplasts were identified by a size of more than $26 \mu \mathrm{m}$ with green chloroplasts (Fig. 2-C). The large fused homokaryotic leaf protoplasts, which could not be identified as to whether they were hybrids, were excluded because the leaf protoplasts lacked ability to divide in any medium. For protoplast fusion $50 \%$ PEG was more effective than the $25 \%$ PEG, but it is unknown whether the high concentration of PEG is harmful to the viable protoplasts.

The hybrid protoplasts and nucellus protoplasts divided within 7-10 days of culture in the $8 \mathrm{p}$ medium containing $0.2 \mathrm{mg} / l 2,4-\mathrm{D}$, $1.0 \mathrm{mg} / l \mathrm{NAA}$ and $0.5 \mathrm{mg} / l \mathrm{BAP}$, while the single leaf protoplasts and fused homokaryotic leaf protoplasts could not divide. The divided 
hybrid cells were identified because they had the green chloroplasts (Fig. 2-D). However, during continuous cell division, the green chloroplasts disappeared (Fig. 2-E) and at the stage of colonies the hybrids were not identified at all (Fig. 2-F).

The colonies were then transferred and form ed calli on MS medium supplemented with 0.1 $\mathrm{mg} / l$ each of IAA and kinetin. We are now trying to analyse by isozymes whether the calli are hybrids. If we can find the hybrid calli, those can be expected to regenrate because of nucellus-derived calli keeping their embryogenetic ability. This, however, has not yet been realized.

\section{Literature Cited}

1. Charles, D. H. and N. A. George. 1984. Isolation and culture of protoplasts from apple callus and cell suspension cultures. J. Amer. Soc. Hort. Sci. 109: 348-350.

2. EichHolts, D. A., H. G. Robitaille and P. M. Hasegawa. 1979. Adventive embryony in apple. HortScience 14: 699-700.

3. Hammerschlag, F. A., G. Bauchan and R. SCORZA. 1985. Regeneration of peach plants from callus derived from immature embryos. Theor. Appl. Genet. 70: 248-251.

4. IsHihARA, A. 1981. Plant regeneration via leaf culture in apple rootstock Malus prunifolia Borkhausen. Abstr. Japan. Soc. Hort. Sci. Autumn Meet. 1981. 42-43. (In Japanese)

5. IshiharA, A. and H. Ooya. 1982. Adventitious embryogenesis in nucellus culture of apple cv. 'Golden Delicious'. Abstr. Japan. Soc. Hort. Sci. Spring Meet. 1982. 84-85. (In Japanese)

6. James, D.J., A.J. Passey, S.B. Malhotra and D. C. DeEming. 1983. Isolation and fusion oì protoplasts from apple and cherry tissues. Rep. E. Malling Res. Sta. for 1982: 150-152.

7. James, D. J., A. J. PAssey and S. B. MALHOTRA. 1984. Isolation and fusion of protoplasts. Rep. E. Malling Res. Sta. for 1983: 63-65.

8. KaO, K. N. and M. R. Michayluk. 1975. Nutritional requirements for growth of Vicia hajastana cells and protoplasts at a very low population density in liquid media. Planta 126: 105-110.

9. Kobayashi, S., H. UChimiYa and I. IKEDA. 1983. Plant regeneration from 'Tro- vita' orange protoplasts. Japan. J. Breed. 33: 119-122.

10. KORBAN, S. S. and R. M. SKIRVIN. 1985. In vitro shoot regeneration from an intact and a sectioned embryo-axis of seeds. Plant Science 39: 61-66.

11. Kouider, M., R. Hauptmann, J. M. WIDHOLM, M. SKIRVIN and S. S. KORBAN. 1984. Callus formation from Malus $\times$ domestica cv. 'Jonathan' protoplasts. Plant Cell Rep. 3: 142-145.

12. KOUIDER, M., R.M. SKIRVIN, S.S. KORBAN, J. M. WIDHORM and R. HAUPMAN. 1984. Adventitious shoot formation from 'Red Delicious' apple cotyledons in vitro. J. Hort. Sci. 59: 295-302.

13. KOUIDER, M., S.S. Korban, R.M. SKirviN and M.C. CHU. 1984. Influence of embryonic dominance and polarity on adventitious shoot formation from apple cotyledons in vitro. J. Amer. Soc. Hort. Sci. 109: 381-385.

14. LiU, J. R., K. C. Sink and F. G. DenNis. 1984. Plant regeneration from apple seedling explants and callus cultures. Plant Cell Tissue Org. Cult. 2: 293-304.

15. MAsuda, T., H. Bessho, S. KOMORI and S. Tsuchiya. 1988. Studies on cell culture and plant regeneration in apple. II. Adventitious shoot formation from the roots of intact micropropagated plantlets. Fruit Trees. Res. Sta. Bul. C. 15: 13-19.

16. Masuda, T., Y. Yoshida, S. TsuchiYa, H. BESSHO and S. KOMORI. 1987. Isolation and culture of apple leaf protoplasts from in vitro cultured shoots. Abstr. The 10th Symposium of Plant Tissue and Cell Culture. 1987. 211. (In Japanese)

17. Mehra, P. N. and S. SAchdeva. 1984. Embryogenesis in apple in vitro. Phytomorphology 34:26-36.

18. Menczel, L. and K. Wolfe. 1984. High frequency of fusion induced in freely suspended protoplasts mixtures by polyethylene glycol and dimethylsulfoxide at high $\mathrm{pH}$. Plant Cell Rep. 3: 196-198.

19. Murashige, T. and F. Skoog. 1962. A revised medium for rapid growth and bioassays with tobacco tissue cultures. Physiol. Plant. 15: 473-497.

20. Nizzeki, M., Y. Hidano and K. Saito. 1983. Callus formation from isolated protoplasts of apple, Malus pumila. Mill. Japan. J. Breed. 33: 369-374.

21. Rubos, A. C. and J. A. Pryke. 1984. Morphogenesis in embryonic tissue culture of apple. J. Hort. Sci. 59: 469-475. 
22. Tsukahara, K., I. Kozaki, M. OOMUra, N. Matsuta and T. Moriguchi. 1985. Adventitious bud formation on apple and quince leaves. Japan. J. Breed. 35. (supp. 2) : 2-3. (In Japanese)

23. Wallin, A. and M. Welander. 1985. Improved yield of apple leaf protoplasts from in vitro cultured shoots by using very young leaves and adding $\mathrm{L}$-methionine to the shoot medium. Plant Cell Tissue Org. Cult. 5: 6972 .

24. YEHIA, M. M. 1985. Shoot regeneration from callus derived from nucellar explant and immature embryo tissue of Williams' bon Chreitien and Conference pear. Rep. E. Malling Res. Sta. for 1984: 245-250.

\title{
リンゴのカルスからの器官形成及びプロトプラストの単離, 培養及び細胞融合
}

\author{
斎藤 彰 $^{1} \cdot$ 新関 稔 $^{2} \cdot$ 斎藤健一 ${ }^{2}$ \\ 1 青森県りんご試験場 $036-03$ 黒石市牡丹平 \\ 2 弘前大学農学部 036 弘前市文京町
}

\begin{abstract}
摘 要
リンゴ, Malus pumila Mill. の珠心由来カルスの再 分化条件について検討した。 さらに，リンゴの細胞融合 による体細胞雑種作出のために, 珠心カルス及び培養シ ュートの葉からプロトプラストを単離, 培養し, 両者の 細胞融合を行った．その結果の概要を以下に示した。

1. 満開後 50 日に採取した品種 ‘らじ’，台木 'CG 80' の珠心由来カルスから低頻度であるが，不定胚が形成さ れた。これらの不定胚は $0^{\circ} \mathrm{C}$ の暗所で 6 力月間処理後, $25^{\circ} \mathrm{C}$ の明所に移したところ，発芽しシュートを形成し た.

2. 珠心カルス及び培養シュートの葉からプロトプラ ストを単離するのに最適な酵素液組成は $2 \%$ Cellulase Onozuka R-10+0.1\% Pectolyase Y-23 又は, $2 \%$ Cellulase Onozuka RS $+0.1 \%$ Pectolyase Y-23 であっ た.

プロトプラスト収量は珠心カルス, 培養シュートとも

しかし, 台木'M. 26’ の培養シュートでは培養後 $21 \sim 30$ 日のものの方が収量が多かった。

プロトプラストの単離に適した酵素処理時間は $3 \sim 4$ 時間であった。

単離されたプロトプラストは植物生長調節物質を含む 8 種の培地で, 培養 60 日後にはコロニー形成した.

3. 珠心カルスと培养シュートの葉から単離したプロ トプラストを融合した，雑種プロトプラストは緑色で, 大きさは 40～ $50 \mu \mathrm{m}$ であった．雑種プロトプラストと透 明な珠心カルスプロトプラストは培養後 7〜10日に細胞 分裂を開始したが，葉肉プロトプラストは細胞分裂しな かった。雑種プロトプラストは数回分裂した時点では, 葉肉プロトプラスト由来の緑色の葉緑体が確認できた。 しかし,コロニー形成の過程で, 緑色の葉緑体は徐々に 消失した。コロニーはカルスまで生長したが，雑種かぞ らか判定できなかった。
\end{abstract} に，新鮮培地に移植後 16〜20日のもので最大となった. 